Dhaka Univ. J. Biol. Sci. 27(2): 175-181, 2018 (July)

\title{
KARYOMORPHOLOGY OF JUSTICIA ADHATODA L. BY DIFFERENTIAL STAINING
}

\author{
Chandan Kumar Dash, Sheikh Shamimul Alam and \\ SYEDA SHARMEEN SULTANA* \\ Cytogenetics Laboratory, Department of Botany, University of Dhaka, \\ Dhaka-1000, Bangladesh \\ Key words: Karyotype, Orcein, CMA, DAPI, Justicia adhatoda
}

\begin{abstract}
Karyomorphological features of Justicia adhatoda L. were investigated in this study after differential staining with orcein, CMA and DAPI for proper characterization. In this species "Simple Chromocenter Type" of interphase nuclei was observed with many small heterochromatin blocks after orcein staining. Prophase chromosomes showed "Interstitial Type" of staining pattern which indicated the tendency of aggregation of heterochromatin in interstitial regions of chromosome. This species was found to possess $2 \mathrm{n}=34$ metacentric chromosomes. The total length of $2 \mathrm{n}$ chromosome complement was $132.17 \mu \mathrm{m}$. Individual chromosome length ranged from 2.57 to $5.43 \mu \mathrm{m}$. The relative length of each chromosome ranged from 0.02 to 0.04 . A total of seven CMA-positive bands were observed in this species whereas no band was found after DAPIstaining. This result suggested the absence of AT-rich portions and occurrence of GC-rich portions in the respective banded chromosomes. Except $2 \mathrm{n}$ chromosome number, the other karyological and fluorescent banding information probably was the first report for this species and it might help to enhance the chromosomal data base with detailed karyomorphological information of this plant species in Bangladesh.
\end{abstract}

\section{Introduction}

Justicia adhatoda L., commonly known as Basok is a medicinal plant native to Asia, widely used in Ayurvedic, homeopathy and Unani systems of medicine ${ }^{(1)}$. This plant belongs to Acanthaceae which possesses about 250 genera and 2,500 species $^{(2)}$. Basok is widely distributed in Sri Lanka, Nepal, Bangladesh, India, Pakistan, Indonesia, Malaysia and China(3). Justicia adhatoda is used as medicine in the treatment of various diseases because it has ability of the formation of secondary metabolites like tannins, alkaloids, saponins, flvanoids, reducing sugars and anthraquinones substances which are in turn used to restore health and heal many diseases ${ }^{(4)}$.

*Author for correspondence: <rumana_botany@yahoo.com>. 
In Bangladesh, leaf juice is used in diarrhea, dysentery, influenza and glandular tumors. Decoction of the leaves is also used in cold, cough and respiratory troubles(3). The recent study revealed that the leaf extract of this plant has some genotoxic and cytotoxic effect $^{(5)}$. From Bangladesh, in total 12 species of Justicia viz. J. adhatoda L., J. andrographioides C. B. Clarke, J. betonica L., J. diffusa Willd., J. gendarussa Burm., J. japonica Thunb., J. oreophila C. B. Clarke, J. peploides (Nees) T. Anders., J. procumbens L., J. punduana Wall., J. tinctoria (Oerst.) D. Gibson and J. vahlii Roth were recorded earlier ${ }^{(3)}$. Among these species J. andrographioides C. B. Clarke, J. diffusa Willd., J. peploides (Nees) T. Anders., J. procumbens L., J. tinctoria (Oerst.) D. Gibson and J. vahlii Roth were considered as restricted to specific region as well as J. oreophila C. B. Clarke and J. punduana Wall. were considered as endangered as it had not been found since J. D. Hooker collected these from Bangladesh(6). At present four species of Justicia viz. J. adhatoda L., J. betonica L., J. gendarussa Burm. and J. japonica Thunb. are commonly distributed throughout the country. The increasing demand of different Justicia species for medicinal uses has caused a serious reduction in native population due to excessive harvest. Moreover, deforestation is another factor for the loss of habitat of this population. The distributions of most of the species of the genus Justicia are restricted in its natural habitat and have also been recognized as 'vulnerable' ${ }^{\prime(3)}$.

In this situation, the development of suitable conservation, management and multiplication strategies for the available species are highly important. For this purpose authentic genetic characterization of species are required. For genetic characterization stable and reliable method must be followed. Karyomorphological study is such a stable and reliable method and it provides basic genetic knowledge of an organism. This includes the nature of interphase nuclei, prophase and metaphase chromosomes i.e. different stages of mitotic cell division. The total karyomorphological behavior enables to characterize even varieties of a species ${ }^{(7,8)}$.

In addition, conventional karyotype with different fluorescent banding is quite satisfactory for detail and critical chromosome analysis such as identification of individual chromosome, determination of amount and location of AT- and GC-rich base pairs in chromosomes, etc. ${ }^{(9,10)}$. DAPI binds to AT-rich repeats giving characteristic blue color bands. On the other hand, CMA binds with GC-rich repetitive sequences of the genome and gives characteristics yellow color bands. With the help of fluorescent staining it is possible to characterize $J$. adhatoda with enhanced genetic knowledge ${ }^{(11,12)}$.

Previous researches were confined mainly to $2 n$ chromosome count $(2 n=34)$ of this species $^{(13-16)}$. Moreover, different chromosome number such as $2 n=56^{(17)}$ and $2 n=50,46^{(13)}$ were also reported indicating the presence of different cytotypes of this species. In this study, a combination of conventional and fluorescent karyotype analysis was undertaken for the first time to obtain genomic information for characterization and proper conservation. 


\section{Materials and Methods}

The species Justicia adhatoda L. was investigated in this study. This species was maintained in the Botanic garden, Department of Botany, University of Dhaka, Bangladesh. Healthy roots were collected and pretreated with 8-hydroxyquinoline $(0.002 \%)$ for $1 \mathrm{hr} 15 \mathrm{~min}$ at $18^{\circ} \mathrm{C}$ followed by $15 \mathrm{~min}$ fixation in $45 \%$ acetic acid at $4^{\circ} \mathrm{C}$ and preserved in $70 \%$ alcohol for future use. These were then hydrolyzed in a mixture of $1 \mathrm{~N}$ $\mathrm{HCl}$ and $45 \%$ acetic acid $(2: 1)$ at $60^{\circ} \mathrm{C}$ for $2 \mathrm{~min}$. The root tips were stained and squashed in $1 \%$ aceto-orcein for $3 \mathrm{hrs}$. Then these slides were observed under a compound microscope (Nikon Eclipse 100). For CMA- and DAPI banding, Alam and Kondo's ${ }^{(10)}$ method was used with slight modification. After hydrolyzing and dissecting, the materials were tapped and squashed with $45 \%$ acetic acid and kept in $-80^{\circ} \mathrm{C}$ freezer (GFL, Germany). The cover glasses were removed quickly and allowed to air dry for at least $24 \mathrm{hrs}$ before study. The air-dried slides were first pre-incubated in Mcllvaine's buffer ( $\mathrm{pH} \mathrm{7.0)}$ for $30 \mathrm{~min}$ followed by Distamycin A $(0.1 \mathrm{mg} / \mathrm{ml})$ treatment for 10 minutes. The slides were rinsed mildly in McIlvaine's buffer supplemented with $5 \mathrm{mM}$ $\mathrm{MgSO}_{4}$ for 15 minutes. One drop of CMA $(0.1 \mathrm{mg} / \mathrm{ml})$ was added and incubated for $1 \mathrm{hr}$ in a humid chamber and then rinsed with Mcllvaine's buffer containing $5 \mathrm{mM} \mathrm{MgSO}_{4}$ for 10 minutes. Slides were mounted in $50 \%$ glycerol and kept at $4^{\circ} \mathrm{C}$ for overnight before observation under Nikon (Eclipse 50i) fluorescent microscope with blue violet (BV) filter cassette. For DAPI-staining, after $24 \mathrm{hrs}$ of air drying, the slides were first pre-incubated in Mcllvaine's buffer (pH 7.0) for $25 \mathrm{~min}$ and treated in Actinomycin D $(0.25 \mathrm{mg} / \mathrm{ml})$ for 10 minutes in a humid chamber. The slides were immersed in DAPI solution $(0.01$ $\mathrm{mg} / \mathrm{ml}$ ) for $1 \mathrm{hr}$ and mounted with 50\% glycerol and observed under a Nikon (Eclipse 50i) fluorescent microscope with UV filter cassette.

\section{Results and Discussion}

Conventional staining: Many prominent darkly stained heterochromatic blocks were observed in the interphase nuclei of Justicia adhatoda L. (Fig. 1). The prophase chromosomes were found to be stained in the interstitial region (Fig. 2). According to Tanaka ${ }^{(18)}$ this type of interphase nuclei and prophase chromosomes could be considered as "Simple Chromocenter Type" and "Interstitial Type", respectively. This species was found to possess $2 n=34$ metacentric chromosomes (Fig. 3) which was also reported earlier(13-16). Thus the present report on the $2 n$ chromosome number of this species correlated with the earlier reports.

The total length of $2 \mathrm{n}$ chromosome complement was $132.17 \mu \mathrm{m}$. The individual chromosome length ranged from 2.57 to $5.43 \mu \mathrm{m}$. The relative length of each chromosome ranged from 0.02 to 0.04 (Tables 1, 2). Having all metacentric chromosomes 

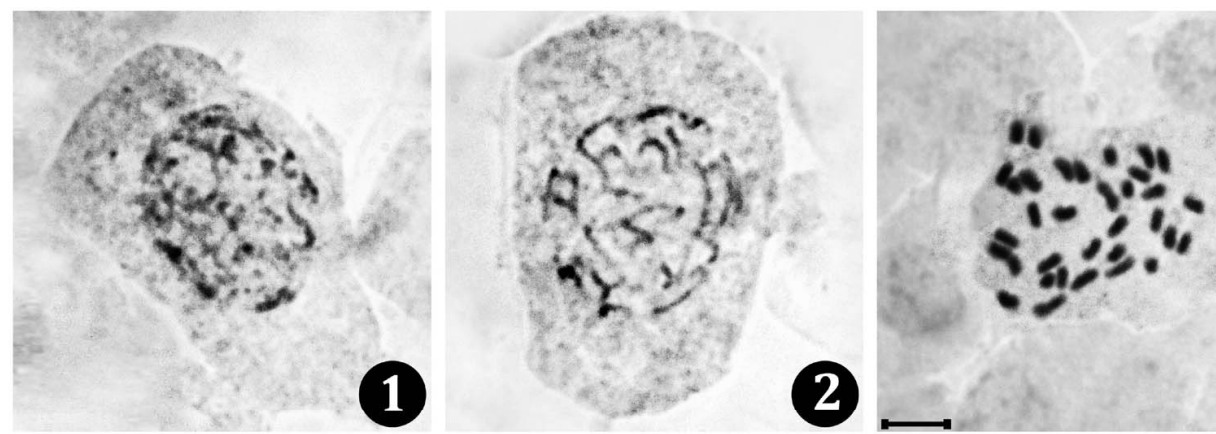

2
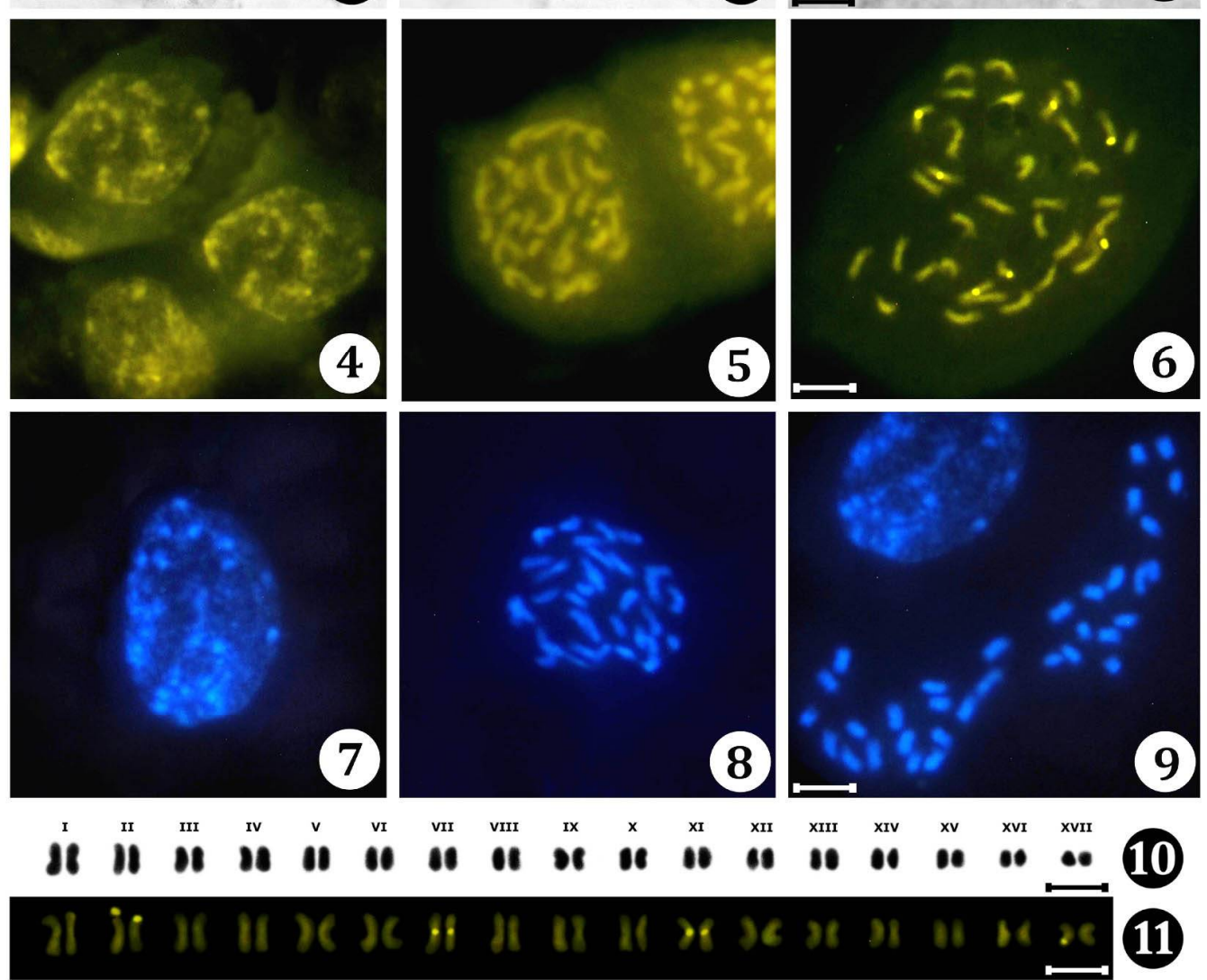

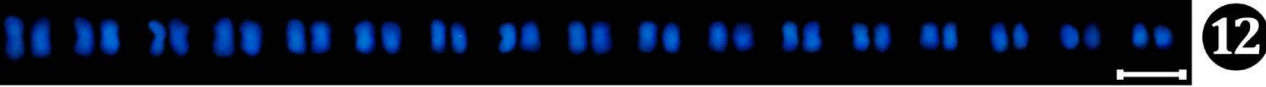

Figs 1-12. Orcein-, CMA- and DAPI- stained mitotic interphase nuclei, prophase chromosomes, metaphase chromosomes and karyotypes of Justicia adhatoda L. 1. Orcein-stained mitotic interphase nuclei, 2. Orceinstained mitotic prophase chromosomes, 3. Orcein-stained mitotic metaphase chromosomes, 4. CMAstained mitotic interphase nuclei, 5. CMA-stained mitotic prophase chromosomes, 6. CMA-stained mitotic metaphase chromosomes, 7. DAPI-stained mitotic interphase nuclei, 8. DAPI-stained mitotic prometaphase chromosomes, 9. DAPI-stained mitotic metaphase chromosomes, 10. Orcein stained karyotype prepared from mitotic metaphase chromosomes, 11. CMA-karyotype prepared from mitotic metaphase chromosomes, 12. DAPI-karyotype prepared from mitotic metaphase chromosomes. Bar $=10 \mu \mathrm{m}$. 
Table 1. Length, arm ratio, centromeric index, relative length and centromeric type of mitotic metaphase chromosomes of Justicia adhatoda $\mathrm{L}$.

\begin{tabular}{|c|c|c|c|c|c|c|c|}
\hline $\begin{array}{l}\text { Chromo- } \\
\text { some } \\
\text { pair }\end{array}$ & $\begin{array}{l}\text { Long } \\
\operatorname{arm}(1) \\
\mu \mathrm{m}\end{array}$ & $\begin{array}{c}\text { Short } \\
\operatorname{arm}(\mathrm{s}) \\
\mu \mathrm{m}\end{array}$ & $\begin{array}{c}\text { Total } \\
\text { length }(\mathrm{T}) \\
\mu \mathrm{m}\end{array}$ & $\begin{array}{c}\text { Arm ratio } \\
(1 / s)\end{array}$ & $\begin{array}{c}\text { Relative } \\
\text { length (RL) }\end{array}$ & $\begin{array}{l}\text { Centro- } \\
\text { meric index } \\
\text { (CI) }\end{array}$ & $\begin{array}{l}\text { Centro- } \\
\text { meric type } \\
\text { (CT) }\end{array}$ \\
\hline \multirow[t]{2}{*}{ I } & 2.85 & 2.58 & 5.43 & 1.10 & 0.04 & 47.51 & $\mathrm{~m}$ \\
\hline & 2.76 & 2.48 & 5.24 & 1.11 & 0.04 & 47.33 & $\mathrm{~m}$ \\
\hline \multirow[t]{2}{*}{ II } & 2.76 & 2.44 & 5.20 & 1.13 & 0.04 & 46.92 & $\mathrm{~m}$ \\
\hline & 2.65 & 2.30 & 4.95 & 1.15 & 0.04 & 46.46 & $\mathrm{~m}$ \\
\hline \multirow[t]{2}{*}{ III } & 2.48 & 1.93 & 4.41 & 1.28 & 0.03 & 43.76 & $\mathrm{~m}$ \\
\hline & 2.35 & 1.98 & 4.33 & 1.19 & 0.03 & 45.73 & $\mathrm{~m}$ \\
\hline \multirow[t]{2}{*}{ IV } & 2.35 & 1.93 & 4.28 & 1.22 & 0.03 & 45.09 & $\mathrm{~m}$ \\
\hline & 2.32 & 1.96 & 4.28 & 1.18 & 0.03 & 45.79 & $\mathrm{~m}$ \\
\hline \multirow[t]{2}{*}{$\mathrm{V}$} & 2.23 & 1.98 & 4.21 & 1.13 & 0.03 & 47.03 & $\mathrm{~m}$ \\
\hline & 2.19 & 1.98 & 4.17 & 1.11 & 0.03 & 47.48 & $\mathrm{~m}$ \\
\hline \multirow[t]{2}{*}{ VI } & 2.19 & 1.98 & 4.17 & 1.11 & 0.03 & 47.48 & $\mathrm{~m}$ \\
\hline & 2.21 & 1.77 & 3.98 & 1.25 & 0.03 & 44.47 & $\mathrm{~m}$ \\
\hline \multirow[t]{2}{*}{ VII } & 2.12 & 1.84 & 3.96 & 1.15 & 0.03 & 46.46 & $\mathrm{~m}$ \\
\hline & 2.14 & 1.77 & 3.91 & 1.21 & 0.03 & 45.27 & $\mathrm{~m}$ \\
\hline \multirow[t]{2}{*}{ VIII } & 2.12 & 1.77 & 3.89 & 1.20 & 0.03 & 45.50 & $\mathrm{~m}$ \\
\hline & 2.09 & 1.77 & 3.86 & 1.18 & 0.03 & 45.85 & $\mathrm{~m}$ \\
\hline \multirow[t]{2}{*}{ IX } & 2.12 & 1.73 & 3.85 & 1.23 & 0.03 & 44.94 & $\mathrm{~m}$ \\
\hline & 2.14 & 1.70 & 3.84 & 1.26 & 0.03 & 44.27 & $\mathrm{~m}$ \\
\hline \multirow[t]{2}{*}{$X$} & 2.05 & 1.73 & 3.78 & 1.18 & 0.03 & 45.77 & $\mathrm{~m}$ \\
\hline & 1.93 & 1.84 & 3.77 & 1.05 & 0.03 & 48.80 & $\mathrm{~m}$ \\
\hline \multirow[t]{2}{*}{ XI } & 1.89 & 1.84 & 3.73 & 1.03 & 0.03 & 49.33 & $\mathrm{~m}$ \\
\hline & 1.91 & 1.79 & 3.72 & 1.07 & 0.03 & 48.12 & $\mathrm{~m}$ \\
\hline \multirow[t]{2}{*}{ XII } & 1.99 & 1.70 & 3.69 & 1.17 & 0.03 & 46.07 & $\mathrm{~m}$ \\
\hline & 1.99 & 1.68 & 3.67 & 1.18 & 0.03 & 45.78 & $\mathrm{~m}$ \\
\hline \multirow[t]{2}{*}{ XIII } & 1.93 & 1.70 & 3.63 & 1.14 & 0.03 & 46.83 & $\mathrm{~m}$ \\
\hline & 1.96 & 1.66 & 3.62 & 1.18 & 0.03 & 45.85 & $\mathrm{~m}$ \\
\hline \multirow[t]{2}{*}{ XIV } & 1.86 & 1.70 & 3.56 & 1.09 & 0.03 & 47.75 & $\mathrm{~m}$ \\
\hline & 1.79 & 1.68 & 3.46 & 1.06 & 0.03 & 48.41 & $\mathrm{~m}$ \\
\hline \multirow[t]{2}{*}{ XV } & 1.77 & 1.63 & 3.40 & 1.09 & 0.03 & 47.94 & $\mathrm{~m}$ \\
\hline & 1.59 & 1.54 & 3.13 & 1.03 & 0.02 & 49.20 & $\mathrm{~m}$ \\
\hline \multirow[t]{2}{*}{ XVI } & 1.56 & 1.43 & 2.99 & 1.09 & 0.02 & 47.82 & $\mathrm{~m}$ \\
\hline & 1.50 & 1.36 & 2.86 & 1.10 & 0.02 & 47.55 & $\mathrm{~m}$ \\
\hline \multirow[t]{2}{*}{ XVII } & 1.33 & 1.29 & 2.62 & 1.03 & 0.02 & 49.24 & $\mathrm{~m}$ \\
\hline & 1.33 & 1.24 & 2.57 & 1.07 & 0.02 & 48.25 & $\mathrm{~m}$ \\
\hline
\end{tabular}

$\mathrm{m}=$ Metacentric chromosome. 
Table 2. Karyomorphological features of Justicia adhatoda L. after differential staining.

\begin{tabular}{|c|c|c|c|c|c|c|c|c|}
\hline $2 n$ & $\begin{array}{l}\text { Total length of } \\
\text { the metaphase } \\
\text { chromosomes } \\
(\mu \mathrm{m})\end{array}$ & $\begin{array}{c}\text { Range of } \\
\text { individual } \\
\text { chromosomal } \\
\text { length }(\mu \mathrm{m})\end{array}$ & $\begin{array}{c}\text { Range of } \\
\text { relative } \\
\text { length }\end{array}$ & $\begin{array}{l}\text { Centro- } \\
\text { meric } \\
\text { formula }\end{array}$ & $\begin{array}{l}\text { No. of } \\
\text { CMA- } \\
\text { bands }\end{array}$ & $\begin{array}{c}\text { \% of } \\
\text { GC-rich } \\
\text { repeats }\end{array}$ & $\begin{array}{c}\text { No. of } \\
\text { DAPI-bands }\end{array}$ & $\begin{array}{l}\text { \% of } \\
\text { AT-rich } \\
\text { repeats }\end{array}$ \\
\hline 34 & 132.17 & $2.57-5.43$ & $0.02-0.04$ & $34 \mathrm{~m}$ & 7 & 5.98 & - & - \\
\hline
\end{tabular}

$\mathrm{m}=$ Metacentric chromosome.

and no gradual decrease of chromosomal length indicated the symmetric nature of karyotype (Figs. 3, 10). According to Stebbins ${ }^{(19)}$, individuals or species with symmetric karyotype are generally primitive in nature. Therefore, J. adhatoda could be considered as primitive species.

Fluorescence banding: In Justicia adhatoda, after CMA staining few scattered small CMA positive bands was observed in interphase nuclei and prophase chromosomes. Seven CMA-positive bands were observed in four different pairs of chromosomes. The total GC-rich region was $7.9 \mu \mathrm{m}$, which occupied about $5.98 \%$ of total chromatin length (Fig. 11, Table 2). Only a pair of satellite was present in pair II. The satellite was extended in one member while contracted at the terminal region of short arm in other member of chromosome pair II. No satellite was observed after orcein and DAPI staining which indicates the stain specific nature of these satellites. Alam and Kundo(10) proposed the presence of stain specific DNA in the satellite portion. In this study, the satellited portion of $J$. adhatoda might have stain specific DNA with GC-rich repeats, thus visible only in CMA. Both the homologue members of chromosome pair VII and XI found to possess similar sized CMA-positive bands in the centromeric region. Heteromorphicity regarding CMA-banding pattern was observed in chromosome pair XVII. A member of this pair had a CMA-positive band in terminal region of its long arm whereas its homologue did not show any band (Fig. 11). The probable reason behind this heteromorphicity might be due to deletion of the banded region from the respective location of the homologous chromosomes. No significant band was found in interphase nuclei, prophase chromosomes and metaphase chromosomes after DAPI-staining revealing the lack of ATrich repeats in the genome of this species (Figs 7-9).

Thus, the detailed karyomorphological information regarding differential staining of chromosome is the first report for this species. The combined data of conventional and fluorescent karyotype will be very useful for authentic cytogenetical characterization which may assist the conservation policies of J. adhatoda in Bangladesh.

\section{Acknowledgement}

The authors are grateful to Professor Dr. Momtaz Begum, Department of Botany, University of Dhaka for kindly indentifying the species of Justicia adhatoda L. 


\section{References}

1. Manjunath BL 1948. The wealth of India, a dictionary of Indian raw materials and industrial products. Coun. Sci. Indus. Res., Delhi, India. pp. 31-32.

2. Airyshaw HK 1973. A dictionary of the flowering plants and ferns (Ed.) J.C. Willis Cambridge: Univ. press. pp. ixxii, 1-1245.

3. Ahmed ZU, ZNT Begum, MA Hassan, M Khondker, SMH Kabir, M Ahmad, ATA Ahmed, AKA Rahman and EU Haque 2008. Encyclopedia of flora and fauna of Bangladesh. Angiosperms: Dicotyledons (Acanthaceae-Asteraceae). Asiat. Soc. Bangladesh 6: 35-42.

4. Kanthale PR and VH Panchal 2015. Pharmacognostic study of Adhatoda vasica Nees. Biosci. Dis. 6(1): 49-53.

5. Borooah DD 2011. Effect of Adhatoda vasica (L.) Nees. Leaf extract prepared by two different methods on mitosis of root meristematic cells of Allium cepa L. J. Adv. Lab. Res. Biol. 2(4): 141-145.

6. Khan MS, MM Rahman and A Ali 2001. Red data book of vascular plants of Bangladesh. Bangladesh National Herbarium, Dhaka, Bangladesh. pp. 179.

7. Khatun M and SkS Alam 2010. Conformation of species status of Corchorus trilocularis by differential chromosome banding and isozyme assay. Cytologia 75(1): 83-88.

8. Khatun M, SS Sultana, H Ara, MN Islam and Sk S Alam 2011. Differential chromosome banding and isozyme assay of three Corchorus spp. Cytologia 76(1): 27-32.

9. Schweizer D 1976. Reverse fluorescent chromosome banding with chromomycin and DAPI. Chromosoma 58: 307-324.

10. Alam SkS and K Kondo 1995. Differential staining with Orcein, Giemsa, CMA and DAPI for comparative chromosome study of 12 species of Australian Drosera (Droseraceae). Amer. J. Bot. 82(10): 1278-1286.

11. Akter S and SkS Alam 2005. Differential fluorescent banding pattern in three varieties of Cicer arietinum L. (Fabaceae). Cytologia 70: 441- 445.

12. Sultana SS, H Ara and SkS Alam 2011. Karyotype analysis with orcein and CMA in two species of Alocasia (Schott) G. Don. Bangladesh J. Bot. 40: 53-56.

13. Datta PC and RK Maiti 1967. Chromosomal biotypes of Adhatoda vasica Nees. growing in the eastern part of India. Cytologia 33: 220-229.

14. Datta PC and P Samanta 1974. Relation between petiole vasculature and karyotypic differences in chromosomal biotypes of Adhatoda vasica Nees. Bot. Gaz. 135(4): 267-275.

15. Sharma S, D Sharma, RK Raghuvanshi, RA Sharma and P Chandrawat 2010. Cytological studies of Adhatoda L. species and Barleria L. species. The Bioscan 5(1): 67-70.

16. Bala S and RC Gupta 2011. Cytological investigations on some north Indian Bicarpellatae. Cytologia 76(3): 261-267.

17. Grant WF 1955. A cytogenetic study in the Acanthaceae. Brittonia 8(2):121-149.

18. Tanaka R 1971. Type of resting nuclei in Orchidaceae. Bot. Mag. Tokyo 84:118-122.

19. Stebbins GL 1971. Chromosomal evolution in higher plants. Addison-Wesley publishing company, California, USA. pp. 208. 